\title{
東京城東病院における総合診療科の立ち上げと活動実績 について
}

The Hospitalist Is Useful in Japanese Small Hospital

\section{森川 暢 ${ }^{1)}$ 松 本真一 ${ }^{2}$ 本橋 伊 織 ${ }^{3)}$ 竹本文美}

Toru Morikawa $^{1)}$, Shinichi Matsumoto ${ }^{2)}$, Iori Motohashi' ${ }^{3)}$, Fumi Takemoto ${ }^{4)}$

\begin{abstract}
要 旨
東京城東病院に平成 27 年から総合診療科が設立された。総合診療科は全ての領域の内科病棟診療, 内科初診外 来, 内科救急を担い院内の中心的存在となった. さらに, 慢性疾患の管理, 地域包括ケア病棟でのリハビリテー ションや緩和ケア，退院支援など多種多様な役割を果たし同院にとって欠かせない存在となった．東京城東病 院における総合診療科の歴史と活動の変遷を報告し小規模病院における総合診療科の有用性について論じる.
\end{abstract}

Keywords : 総合診療科 (Hospitalist), 小規模病院 (Community hospital)

\section{はじめに}

平成 27 年に独立行政法人地域医療機能推進機構 (以 下 JCHO）の東京城東病院（以下当院）に総合診療科 (旧称：総合内科)が立ち上がった。その実績を報告し 小規模病院における総合診療科の有用性について論じ る.

\section{当院周囲の状況}

当院は東京都江東区北東端の江戸川区との境に位置 する病床数 130 (実質稼働 124) の病院である（平成 30 年度時点). 江東区, 江戸川区, 墨田区の 3 区は東京都 区東部医療圈と呼称され人口約 140 万人の巨大な医療 圈であるが, 人口 10 万人あたりの病床数は 470.3 (全国 平均 693.9) と比較的少なく病院の需要が高い地域であ る (平成 27 年度 $)^{1)}$. しかし同医療圈には救命救急セン ターは 1 箇所のみであり救急医療の需要があることが 窺える. 当院は都営新宿線東大島駅と JR 総武線亀戸 駅の中間地点に位置しているが, 多くの診療所は駅周 辺に存在しているため当院は近隣の住民にとって最も 近い医療機関のひとつである。

\section{当院の総合内科誕生時の現状と課題}

当院は 130 床規模の小規模病院ながら内科, 整形外 科, 消化器外科はそれぞれ, 大学の関連病院として医 師が派遣されていた. しかし平成 16 年の新医師臨床研 修制度の開始に伴い大学医局に医師が引き上げられ た. 平成 26 年に JCHO に経営が譲渡された当時, 内科 医は平成 19 年の 8 人から 3 人へと減少していた. 平成 26 年度の病院全体の病棟稼㗢率は $61.9 \%$ であった ${ }^{2}$. 医師の減少とともに職員の士気も低下し地域住民や診 療所からの医療要請に応じられない状態であった.

\section{総合内科創設}

$\mathrm{JCHO}$ は地域医療, 地域包括ケアの要として地域住 民の多様なニーズに応え, 地域住民の生活を支えるこ とが使命であることから, 総合診療医の育成にかじ取 りを切り総合診療医である徳田安春医師（現, 群星沖 縄臨床研修センター長）を顧問として招聘した．東京 に総合診療医育成の拠点を作る目的と内科医不足を解 消する目的の両者を解決するために，当院に総合内科

\footnotetext{
1)市立奈良病院

2) 悠翔会在宅クリニック北千住

3) 聖マリアンナ医科大学多摩病院

4)独立行政法人地域医療機能推進機構東京城東病院

著者連絡先：森川 暢 市立奈良病院［７６30-8305 奈良県奈良市東紀寺町 1 丁目 50-1］

email: aquariusmed@gmail.com

(受付日：2020 年 1 月 14 日, 採用日：2020 年 4 月 6 日)

(C)2020 日本プライマリ・ケア連合学会
} 


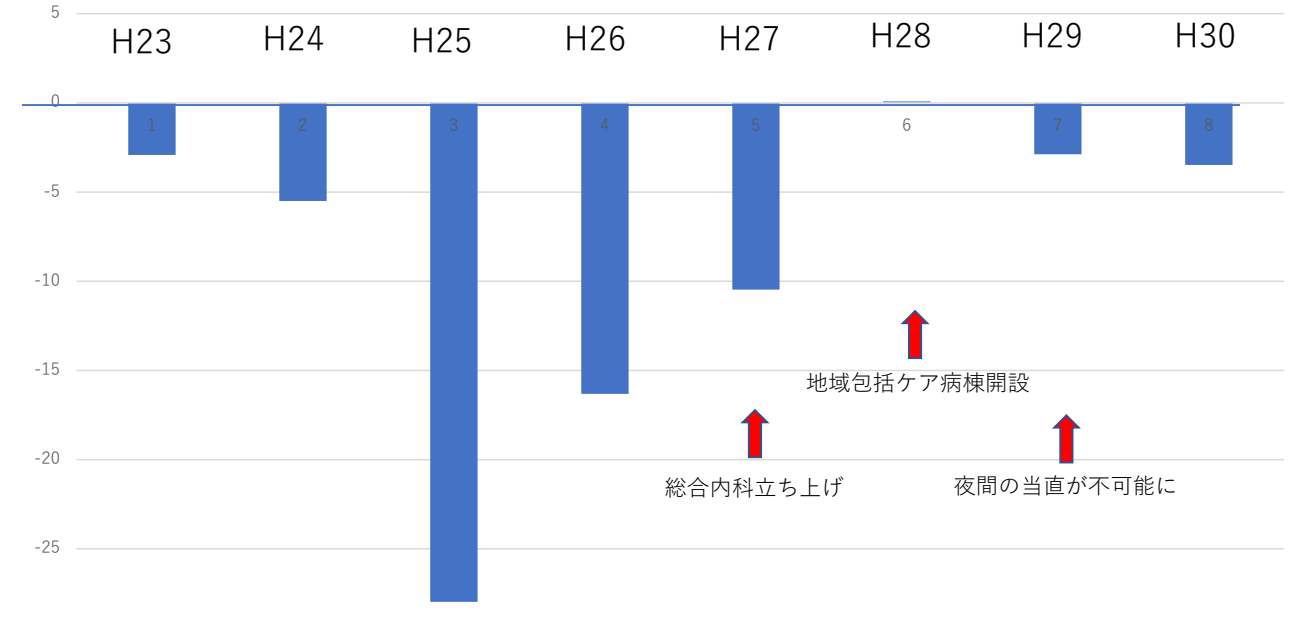

$-30$

\begin{tabular}{|c|c|c|c|c|c|c|c|c|}
\hline & $\mathrm{H} 23$ & $\mathrm{H} 24$ & $\mathrm{H} 25$ & $\mathrm{H} 26$ & $\mathrm{H} 27$ & $\mathrm{H} 28$ & $\mathrm{H} 29$ & $\mathrm{H} 30$ \\
\hline 経常利益率 & $-2.92 \%$ & $-5.5 \%$ & $-28.0 \%$ & $-16.3 \%$ & $-10.5 \%$ & $0.1 \%$ & $-2.9 \%$ & $-3.5 \%$ \\
\hline 急性期病床利用率 & $65.70 \%$ & $61.90 \%$ & $61.90 \%$ & $61.90 \%$ & $77.30 \%$ & $80.90 \%$ & $78 \%$ & $73.10 \%$ \\
\hline 地域包括ケア病床利用率 & $0 \%$ & $0 \%$ & $0 \%$ & $0 \%$ & $0 \%$ & $98.10 \%$ & $97.80 \%$ & $97.80 \%$ \\
\hline 内科救急車数(年間) & 250 & 229 & 191 & 303 & 1630 & 1174 & 566 & 520 \\
\hline
\end{tabular}

図 1 東京城東病院の年度ごとの経常利益率の推移

を立ち上げることになった. 平成 26 年度より和足孝之 医師（現, 島根大学卒後臨床研修センター）が立ち上 げの準備の為に赴任し, 内科系救急を受け入れ始めた。 平成 27 年度より志水太郎医師 (現, 獨協医科大学総合 診療医学・総合診療科教授）を総合内科の現場責任者 として立ち上げを行い，指導医 7 人, 後期研修医 9 人, 診療看護師 2 人が集まった。

\section{総合内科の発展}

平成 28 年度より志水医師の異動に伴い筆者が現場 責任者を受け継ぎ， 3 病棟あった急性期病棟のうちの 1 病棟を地域包括ケア病棟に変更した. 平成 28 年度末 に働き方改革で医師の長時間勤務が難しくなり, 夜間 の当直を非常勤医師に委ねたため, 平成 29 年度の救急 応需件数は減少した. 平成 30 年度より新専門医制度が 開始され総合診療専門医の育成も開始する方向とし, 科の名称も総合診療科に変更した.

\section{財務面の成果}

平成 27 年から総合内科が設立してから内科系救急 応需数㧍よび病床稼働率が増加し経常利益率は改善し た. 平成 28 年度に地域包括ケア病棟が開設しさらに病 床稼働率は増加し経常利益率は黒字に転じた. 平成 29 年度より救急応需数減少で急性期病棟の病床稼働率も 減少し経常利益率は再度赤字になった。しかし近隣の 急性期病院から積極的に転院を受け入れることで地域
包括ケア病床の病床稼働率を維持した結果，経常利益 率は $3 \%$ 前後の赤字で留まった（図 1).

\section{非財務面の成果}

平成 30 年度の時点で総合診療科には合計 8 人の医 師が抢り, 全領域の内科急性期病棟, 内科初診外来, 内科救急診療, 地域包括ケア病棟での診療を担い, 病 院における中心的存在となった. 地域からの医療要請 にも応えることが出来るようになり職員の士気も向上 した。 循環器内科, 腎臓内科, 呼吸器内科の常勤内科 医は外来業務及び総合診療科のコンサルタントとして の役割を主に担うようになった，総合診療科はカン ファレンスや教育回診, 講師受け入れを積極的に行っ たため, 常時 4 人前後の後期研修医が総合診療科に在 籍した。また他科から総合診療科に転科する医師の研 修も積極的に受け入れた。

\section{考 察}

200 床未満の病院は小病院と定義される ${ }^{3}$. 日本の全 病院 8,605 病院のうち, 約 7 割が 200 床未満の小規模 病院である ${ }^{4)}$. 当院も小規模病院に分類されるが, 前野 らの研究に扔ける小規模病院での報告も踏まえて考察 する ${ }^{5}$. 奈良県立五條病院の報告では総合内科を立ち上 げることで内科救急の受け入れ数と急性期病棟の入院 稼働率が増加した5). 穎田病院の報告では地域包括ケア 病棟や在宅医療での家庭医の教育により, リクルート 
や教育面の効果があった ${ }^{5)}$. 当院でも, 平成 27 年度か らの総合内科立ち上げに伴い内科救急の応需数と, 急 性期病棟の入院稼働率が上昇した。ささらに地域包括ケ ア病棟を開設し他院からの転院症例を受け入れること でさらに病棟稼働率が上昇し財務面で改善を認めた。 総合診療医を目指す若手医師にとっては, 幅広い急性 期内科疾患のみならずリハビリや緩和ケア, 退院支援 も含めた幅広い研修が可能であったため, リクルート や教育の面で有利に働いた. 平成 16 年に打ける当院の ように専門内科医が多数在籍した時点と比べると専門 手技では劣るものの，幅広く内科系救急を受け入れる ことが出来る点は総合診療科のほうが優れていると考 える。また地域包括ケア病棟入院料 1 は 200 床未満の 病院でのみ算定できることからも小規模病院における 地域包括ケア病棟への期待が高いことが窺える ${ }^{6}$. 地域 包括ケア病棟の運営に関してはリハビリ，緩和ケア， 退院支援，にも強いという点で総合診療科が有利であ る. 以上の当院での活動および考察からも小規模病院 では総合診療科が有用であることが示唆される。しか し，運営が属人的になり中心となる人物次第で科が存 続できるかが決定される点, 専門医不在である分野で 質が低下する点が欠点であり，今後の課題である.

\section{文 献}

1）日本医師会. 地域医療情報システム。東京. [not revised; cited 24 January 2020]. Available from: http://jmap.jp/cit ies/detail/city/13108

2）地域医療機能推進機構 (JCHO). 財務諸表. 東京. [not revised; cited 10 January 2020]. Available from: https://w ww.jcho.go.jp/\%E8\%B2\%A1\%E5\%8B\%99\%E8\%AB\%B 8\%E8\%A1\%A8/

3）内閣府政策統括官（経済財政分析担当）。公立病院経営の 状況と小規模公立病院の経営課題一持続可能な地域の医 療提供体制の確立へ向けて一 東京. [not revised; cited 24 January 2020]. Available from: https://www5.cao.go.j p/keizai3/2017/08seisakukadai12-0.pdf

4）厚生労働省. 第 3 回病床機能情報の報告 - 提供の具体的 なあり方に関する検討会. 東京. [not revised; cited 10 January 2020]. Available from: https://www.mhlw.go.jp/ stf/shingi/2r9852000002rad0-att/2r9852000002skuh.pdf

5）前野哲博. 総合診療が地域医療における専門医や他職種 連携等に与える効果についての研究. 厚生労働行政推進 調査事業費補助金 (厚生労働科学特別事業) 第 6 部 総 合診療医の活動に関するモデルとなる事例集 (1). [not revised; cited 3 February 2020]. Available from: https:// mhlw-grants.niph.go.jp/niph/search/NIDD00.do?resrch Num $=201706032 \mathrm{~A}$

6) 厚生労働省. 地域包括ケア病棟のイメージと要件一東京. [not revised; cited 3 February 2020]. Available from: http s://www.mhlw.go.jp/file/06-Seisakujouhou-12400000-Ho kenkyoku/0000039380.pdf

\section{利益相反}

開示すべき利益相反なし 